\title{
Use of Agro-Energy Waste as Agricultural Inputs: Impact on Soil Bacterial Diversity
}

\section{Bruno Oliveira de Carvalho1, Rafael Antônio Presotto², Jéssica de Oliveira Lima ${ }^{1}$, Shana de Mattos de Oliveira Coelho ${ }^{1}$, Miliane Moreira Soares de Souza', Everaldo Zonta², Irene da Silva Coelho'}

\begin{abstract}
${ }^{1}$ Veterinary Microbiology and Immunology Department, Veterinary Institute, Federal Rural University of Rio de Janeiro, Seropedica, Rio de Janeiro, Brazil

${ }^{2}$ Department of Soil, Agronomy Institute, Federal Rural University of Rio de Janeiro; Seropedica, Rio de Janeiro, Brazil.
\end{abstract}

\begin{abstract}
Waste reuse is a very interesting option from an economic, environmental, and often a social point of view. However, it is important to assess the impact of their use on soil characteristics to optimize proper dosages. Because microbial diversity can be used as one of the indicators of soil quality; we aimed to evaluate soil bacterial diversity after using combinations of gravel (waste from drilling in the petroleum industry) and Crambe press-cake (a by-product of biodiesel production) in haplic planosol cultivated with sunflowers (Helianthus annus 1.) using a culture-independent technique, Denaturing Gradient Gel Electrophoresis (DGGE). Analysis of variance showed that the use of gravel and Crambe press cake at doses tested in haplic planosol did not significantly affect soil microbial diversity. This wastes had no significant effect on the number of bands obtained using DGGE. Besides, dynamics of the bacterial population did not follow any other parameter, such as chemical parameters, evaluated in the study, confirming that changes in the chemical characteristics of the soil due to the application of the wastes did not affect bacterial diversity. The results indicate that the use of these wastes is environmentally safe and that higher sodium content did not affect soil bacteria diversity.
\end{abstract}

Keywords: Crambe press cake, Denaturing Gradient Gel Electrophoresis (DGGE), microorganisms, Oil well drilling gravel, planosol.

\section{Introduction}

Brazil's oil reserves have increased substantially with the discovery of pre-salt oil deposits. In addition to the pollutants emitted when petroleum is used, the industry produces gaseous and liquid effluents as well as solid wastes that can be harmful to the environment and to public health. Gravel from drilling is prominent among the wastes produced by oil well operations. The amount generated may vary in exploratory wells from 200 to 1000 tons, and its significant polluting potential depends on the drilling fluid used (Dias et al., 2004).

Drilling fluids are mixtures of different components used when wells are drilled, including barium (Ba) and sodium $(\mathrm{Na})$, which are the most significant, along with hydrocarbons and heavy metals in some cases (Fam and Dusseault, 1998). However, preliminary studies have shown that the presence of $\mathrm{Na}$ and total petroleum hydrocarbons (TPH) in gravel mainly limit its use in agriculture. $\mathrm{Ba}$ has been exonerated as a contaminant because of its low bioavailability in the form of barium sulfate (Magalhaes et al., 2012).

The disposal of gravel and its uses in soil remain to be studied in detail. However, Freitas et al. (2015) have shown that if the problems related to possible contaminants are overcome, gravel may be used to improve soil chemical properties, with consequent improvements in soil characteristics related to fertility and soil physics.

This article is published under the terms of the Creative Commons Attribution License 4.0

Author(s) retain the copyright of this article. Publication rights with Alkhaer Publications.

Published at: http://www.ijsciences.com/pub/issue/2016-06/

DOI: 10.18483/ijSci.1070; Online ISSN: 2305-3925; Print ISSN: 2410-4477 
Seeking alternatives to using fossil fuels is a worldwide trend. Initiatives related to the use of ethanol and biodiesel are attracting global attention by offering economically and ecologically viable alternatives to fossil fuels. Agriculture-derived energy is less polluting and cheaper and represents the second most important source of primary energy in Brazil. The production of vegetable oil, the raw material for biodiesel production, generates byproducts. The long-term accumulation of these organic wastes without adequate treatment creates environmental and health risks. However, Petrobras developed a new technology for manufacturing biodiesel, which produces this fuel directly from seeds (of any oleaginous plant) without the need to extract the oil in a previous step (Freitas, 2009; Presotto, 2014). Both processes generate a residue called press cake.

Using waste from the agro-energy and petroleum industries in agriculture helps decrease losses from improper disposal. Considering agriculture, the main advantage of using by-products depends on the nutrients they comprise and/or benefits linked to their organic content, which can maintain or even increase organic matter content in soil and correct soil acidity (Marciano et al., 2001; Pires et al., 2008). However, this strategy should be seriously treated, and studies monitoring its impact should be conducted to prevent the occurrence of larger problems (Oliveira, 2008). Crame abyssinica is an alternative winter crop for biodiesel production. One of its by-products is press cake, which can be used as a protein source in ruminant feed (Silva, 2013). Oil crop press cakes, such as Crambe press cake, exhibit a potential use as a fertilizer; however, studies related to this usage are still scarce. In this study, Crambe press cake was used to assess whether its addition might attenuate salinity rates produced by gravel.

Araújo and Monteiro (2007) have defined soil quality as its ability to function within the ecosystem to sustain biological productivity, maintain environmental quality, and promote the health of plants and animals. Evaluation of physical, chemical, and biological processes or properties is essential for soil quality analysis. These properties together are known as indicators of soil quality. Biological indicators are related to biomass and microbial diversity, nutrient mineralization, and soil respiration. Microorganisms are the base of the food chain and are intrinsically associated with various soil ecological processes. Microbial diversity has been found to be an important indicator of soil quality (Zilli et al., 2003).

Microbial structural diversity is currently being studied using methods based on the investigation of partial environmental DNA sequences, particularly the $16 \mathrm{~S}$ rDNA gene for bacteria and the $18 \mathrm{~S} \mathrm{rDNA}$ gene for fungi. The sequences are amplified using polymerase chain reaction (PCR) and subsequently characterized by cloning and sequencing or analyzed by electrophoresis using ARDRA, T-RFLP, RAPD, RISA, DGGE/TGGE, and SSCP methods to obtain microbial community profiles. This type of analyses has become very popular to help identify unknown bacteria (Elsas and Smalla, 1995; Derakshani et al., 2001; Torsvik and Ovreas, 2002).

Denaturing gradient gel electrophoresis (DGGE) was first used by Muyzer et al. (1993) to assess microbial diversity. PCR products are separated in polyacrylamide gels containing a denaturant gradient with increasing concentrations of formamide and urea. The separation of similar-sized fragments with different nucleotide composition is based on the electrophoretic mobility of the partially denatured DNA molecules in the polyacrylamide gels. Variations in the nucleotide composition of the different DNA fragments determine their migration behavior in the gel, causing fragments with different compositions to stop at different positions in the gel. Migration of the DNA fragments in DGGE is determined not only by nucleotide composition but also by the interactions between these nucleotides within the molecule (Breslauer et al., 1986). DGGE enables the investigation of microbial communities in the soil and can indicate changes in the composition of this community resulting from anthropogenic activities (Ferreira, 2009).

Development of strategies to reuse wastes generated by the agro-energy and petroleum industries is crucial. In particular, this is relevant if the waste reuse involves improving soil quality of oil crops areas to produce biofuels. However, data in the field is still lacking. Thus, we aimed to evaluate the impact of waste application, such as gravel obtained from drilling oil wells and press cake resulting from pressing Crambe abyssinica, on bacterial diversity in soil cultivated with sunflowers.

\section{Materials and Methods \\ Experimental setup and activities in the greenhouse}

The experiment was conducted in the greenhouse of the Soils Department in the Agronomy Institute of the Rural Federal University of Rio de Janeiro, Brazil.

The experimental design was factorial $(3 \times 3)$ and composed of three doses of gravel $(0,30$, and $60 \mathrm{Mg}$ ha-1) and Crambe press cake $(0,16$, and $32 \mathrm{Mg}$ ha-1) in a completely randomized design. In these soils, sunflower (Helianthus annus 1.) seedlings were sown, summing up to nine plots or experimental units used in this study.

Each plot consisted of $8 \mathrm{dm}-3$ soil along with the 
respective treatments. The treatments were mixed with the soil in a concrete mixer for $5 \mathrm{~min}$; the resulting mixture was placed into pots, and water was added until $70 \%$ of field capacity was attained. Fortytwo days after the treatment mixtures were placed in the pots, 10 sunflower seeds were sown in each plot. After germination, the two most vigorous plants were chosen from each plot, and these were grown for 45 days in the greenhouse. After the plants were cultivated, a sample of soil was collected from each plot and stored at $-20^{\circ} \mathrm{C}$ until analysis.

The soil used in this assay was collected from the surface layer $(0-20 \mathrm{~cm})$ of haplic planosol (EMBRAPA, 2013) located in the municipality of Seropédica, RJ. After collection, the soil was dried in shade and sieved through a 4-mm mesh. To calculate the dose in $\mathrm{Mgha}-1$, a soil depth of $0.2 \mathrm{~m}$ was considered. This soil is composed of 596, 132, and $272 \mathrm{~g} \mathrm{~kg}-1$ of sand, silt, and clay, respectively.

Table 3Error! Reference source not found. presents the concentrations of nutrients $(\mathrm{N}, \mathrm{P}, \mathrm{K}+$, $\mathrm{Ca} 2+, \mathrm{Mg} 2+, \mathrm{Fe}, \mathrm{Cu}, \mathrm{Mn}$, and $\mathrm{Zn}$ ) in the Crambe press cake and gravel used in the experiment and the level of total petroleum hydrocarbons (TPH) in the gravel.

\section{Direct DNA extraction from soil}

Total extraction of the DNA from soil was performed using the PowerMax ${ }^{\mathrm{TM}}$ Soil DNA Isolation kit (MO BIO Laboratories, Inc), according to the manufacturer's instructions. Samples were stored at $-20^{\circ} \mathrm{C}$, and DNA quantity and quality were evaluated by electrophoresis using $0.8 \%$ agarose gel combined with SYBR Safe DNA Gel Stain (Invitrogen).

\section{Polymerase Chain Reaction (PCR) of the 16S rDNA region of bacteria}

To increase sensitivity and facilitate the examination of similar-sized fragments, nested PCR was used. The first PCR used $1 \mathrm{U}$ of Taq DNA polymerase (Fermentas), $1 \times$ reaction buffer, $200 \mu \mathrm{M}$ of each $\mathrm{dNTP}, 3.0 \mathrm{mM}$ of $\mathrm{MgCl} 2$, and $0.5 \mu \mathrm{M}$ of $27 \mathrm{f}$ primer (Suzuki and Giovannoni, 1996) and 1512r primer (Kane et al., 1993). The amplifications were conducted as follows: $5 \mathrm{~min}$ initial denaturation at $94^{\circ} \mathrm{C}, 30$ cycles at $94^{\circ} \mathrm{C}$ for $60 \mathrm{~s}, 55^{\circ} \mathrm{C}$ for $60 \mathrm{~s}$, and $72^{\circ} \mathrm{C}$ for $60 \mathrm{~s}$, followed by a final elongation at $72^{\circ} \mathrm{C}$ for $10 \mathrm{~min}$. PCR products $(5 \mu \mathrm{L})$ were separated by electrophoresis in $1.5 \%$ agarose gel combined with SYBR Safe DNA Gel Plus Stain (Invitrogen), and the gel was viewed under 254-nm UV light. The products of the first reaction were used as a template for the second PCR using primers CG 338f and 518r, which amplify the $\mathrm{V} 3$ region of $16 \mathrm{~S}$ rDNA (Ovreas et al., 1997). The amplifications were conducted as follows: 5 min initial denaturation at $94^{\circ} \mathrm{C}, 30$ cycles at $94^{\circ} \mathrm{C}$ for $60 \mathrm{~s}, 55^{\circ} \mathrm{C}$ for $60 \mathrm{~s}$, and $72^{\circ} \mathrm{C}$ for $60 \mathrm{~s}$, followed by a final elongation at $72^{\circ} \mathrm{C}$ for $5 \mathrm{~min}$.
Denaturing Gradient Gel Electrophoresis (DGGE) Products of the second PCR were evaluated using $8 \%$ polyacrylamide gel with a concentration gradient ranging from $44 \%$ to $60 \%$ defined from a mixture of urea and deionized formamide solutions. Electrophoresis was performed at $70 \mathrm{~V}$ and $60^{\circ} \mathrm{C}$ for $16 \mathrm{~h}$ using a DcodeTM Universal Mutation Detection System device (Bio-Rad, Richmond, USA). The gels were photographed and the images were analyzed using Bionumerics software (Applied Maths, StMartens-Latem). Differences were determined using the Dice coefficient, and the unweighted pair group method with arithmetic mean algorithm was used for the grouping analysis. Richness represents the number of bands in the DGGE gel, which refers to the operational taxonomic units (OTU).

\section{Recovery of DGGE bands and analysis of sequences}

Some bands were selected for identification by sequencing. They were excised from the gel using a sterilized scalpel blade, and the DNA was eluted in $10 \mu \mathrm{L}$ of ultrapure water for $16 \mathrm{~h}$ at $4^{\circ} \mathrm{C}$. After incubation, this material was centrifuged for $1 \mathrm{~min}$ at $124 \times \mathrm{g}$, and an aliquot of $2 \mu \mathrm{L}$ was used for amplification by PCR using the 338f/518r primers. The amplifications were conducted as follows: $5 \mathrm{~min}$ initial denaturation at $94^{\circ} \mathrm{C}, 30$ cycles at $94^{\circ} \mathrm{C}$ for 60 $\mathrm{s}, 55^{\circ} \mathrm{C}$ for $60 \mathrm{~s}$, and $72^{\circ} \mathrm{C}$ for $60 \mathrm{~s}$, followed by a final elongation at $72^{\circ} \mathrm{C}$ for $5 \mathrm{~min}$. PCR products were purified using the QIAquick Gel Extraction Kit (Qiagen, Hilden, Germany) and then sequenced using the ABI Applied Biosystems 3130xl sequencer at the genomic sciences and biotechnology laboratory of the Catholic University of Brasilia. Both sequences will be sequenced to ensure fidelity and will be analyzed in the Sequence Bioedit Alignment Editor program. The sequences will be subjected to the BLASTn algorithm, allowing comparison with nucleotide sequences stored in the NCBI database (GenBank; http://www.ncbi.nlm.nih.gov/) and inference of species.

\section{Statistical analysis}

Analysis of variance was performed for data on the number of gel bands in the DGGE gel using the Ftest for each factor (Crambe press cake, gravel, and interaction). The Pearson correlation coefficient between the number of bands and the other variables was also obtained. Statistical analyses were performed using the SAS program (SAS Institute, Inc. 2010).

\section{Results and Discussion}

DNA extracted from the soil samples had a high molecular weight and proved suitable for use as a template for PCR. The bacterial primers amplified regions of the $16 \mathrm{~S}$ rDNA gene from the 27 th $(27 \mathrm{~F})$ to the 1512 th $(1512 \mathrm{R})$ position, whereas $338(\mathrm{GC}-338 \mathrm{~F})$ 
and $518(518 \mathrm{R})$ were relative to the rDNA nucleotide sequence of Escherichia coli, generating fragments of 1500 and $198 \mathrm{bp}$, respectively. Amplicons of approximately $198 \mathrm{bp}$ produced using nested PCR were subjected to DGGE (Fig. 1A). The migration profile in the DGGE gel revealed DNA fragments of the same size but different base sequences (OTUs). This offered an overview of the bacterial community structure in nine samples of haplic planosol treated with different wastes from the agro-energy industry. It was observed from the duplicates that the profile obtained for each sample is reproducible with only minor differences.

Some bands, represented by solid arrows in the gel (Fig. 1A), were present in all the samples, suggesting that some bacteria remained in the soil regardless of the treatment. However, bands at various positions within the DGGE profiles (as shown by the dotted arrows) indicated different OTUs (of individuals and/or communities) and may be related to soil management, such as the addition of by-products.

Considering the richness values, sample 30/32 (30 $\mathrm{Mg}$ ha-1 gravel and $32 \mathrm{Mg}$ ha-1 Crambe press cake) showed the highest number of OTUs (27.5), indicating that this combination presented the greatest bacterial diversity. Table 1 presents the average of the sum of the number of bands (OTUs) in each sample (richness value) in both DGGE gels analyzed, enabling the analysis of bacterial diversity dynamics. Bacterial richness increased when $16 \mathrm{Mg}$ ha- 1 and $32 \mathrm{Mg}$ ha-1 Crambe press cakes were used without gravel or when combined with $30 \mathrm{Mg}$ ha-1 gravel. However, combining Crambe press cake with $60 \mathrm{Mg}$ ha-1 gravel compromised diversity because a decrease in the number of OTUs was observed. However, analysis of variance for the richness values (number of OTUs) from the DGGE revealed no significant effect from varying doses of gravel $(\mathrm{P}=$ $0.68331)$, Crambe press cake $(\mathrm{P}=0.4937)$, and both $(\mathrm{P}=0.3619)$ on soil bacterial diversity.

DGGE results demonstrated that gravel and Crambe press cake, at the doses tested in haplic planosol, did not significantly affect soil microbial diversity because no significant effect on the number of bands (OTUs) was observed. This indicates that adding gravel and Crambe press cake had no or a very little impact on bacterial diversity. This information is important because it contradicts the hypothesis that large amounts of gravel compromise the diversity of bacterial population and consequently soil quality.

Although the levels of gravel and Crambe press cake did not significantly affect bacterial richness, we observed a difference in bacterial community structure according to the treatment based on the presence of different amplicons (OTUs) in the DGGE profiles for each sample tested (Fig. 1A). Microbial population behavior depends on the quality and the quantity of wastes added to the soil. This may have an impact on the dynamic balance of populations in the soil bacterial community, which might be modified. Moreover, there were bands present in all treatments. It is possible that these bacteria were established in this environment prior to the experiment. Communities of microorganisms preestablished in an environment cannot be considered as bioindicators of soil quality because they do not reflect impacts from the application of the gravel.

In addition to the number of OTUs, similarity between treatments was determined using the similarity matrix generated by the Jaccard coefficient to creating a dendrogram, forming groups with $<60 \%$ similarity up to a group with $78 \%$ similarity (Fig. 2). Two large groups were obtained. The first group contained the following samples: $0 / 0,0 / 16,0 / 32$, $30 / 0$, and $30 / 16$ ( $\mathrm{Mg} \mathrm{ha}-1$ gravel/Crambe press cake), and the second group contained the following samples: 30/32, 60/0, 60/16, and 60/32 (Mg ha-1 gravel/Crambe press cake). Dendrogram analysis revealed that samples that received $60 \mathrm{Mg}$ ha-1 gravel belonged to the same group because they displayed the same bacterial profile. This result indicates that although the addition of gravel did not directly increase bacterial diversity, a specific bacterial population was favored. These bacteria were also present in the sample with the greatest diversity.

Nineteen bands were excised from the DGGE gel and sequenced to obtain information on some of the bacterial populations present in all the treatments and those favored by only some treatments. The positions of the sequenced bands are shown in Fig. 1B. Table 2 shows the results of sequencing, i.e., the similarity values compared with the related sequences available in Genbank. However, it was possible to identify the genus Virgibacillus sp. and Bacillus sp in only 2 of the 19 selected bands. The others exhibited similarity to non-cultivable bacteria. The search for bacteria in the soil has been effective in expanding the knowledge about their diversity, enabling new species discoveries and reports and opening up the possibility of future utilization of these species for various purposes (Kirk et al., 2004). An important result of this study was the sequencing of the DGGE gel bands and identification of the bacterial species in the samples. These data are important to determine whether bacterial species or communities in wastetreated soils were affected.

Table 1 shows that the levels of parameters, such as $\mathrm{Na}$, potassium, calcium, and magnesium, increased with increased doses of gravel and Crambe press cake. This variation did not follow the dynamics of bacterial diversity. Furthermore, the correlation between the number of OTUs obtained using DGGE 
and other variables in the experiment was analyzed. The P-value of the comparison was $\mathrm{pH} \times \mathrm{OTU}=$ 0,$337271 ; \mathrm{Na} \times \mathrm{OTU}=0,555242 ; \mathrm{K} \times \mathrm{OTU}=$ 0,$263779 ; \mathrm{Ca} \times$ OUT $=0,399176 ; \mathrm{Mg} \times$ OUT $=$ 0,240598 ; press cake $\times$ OUT $=0,091258$; gravel $\times$ OUT $=0,603871$. The results showed no significant correlation between these factors and the number of OTUs. These results confirm that changes in chemical characteristics of the soil due to waste application did not affect bacterial diversity.

In conclusion, in this study, bacterial diversity in the different treatments was not negatively affected on applying gravels and Crambe press-cake to the soil, which indicates that the use of this waste is environmentally safe. Besides, the higher sodium content did not seem to affect the bacteria in the soil. The understanding of these dynamics and measurement of the effects of this waste in soil may contribute to the management of gravel and press cake, enabling their reuse in the environment in a safe and responsible manner.

\section{Acknowledgments}

We thank PETROBRAS and FAPERJ for financial support for this work. We also thank FAPERJ for the undergraduate research scholarship.

\section{Conflicts of interest}

No conflict of interest declared.

\section{References}

1. Araújo, A.S.F., Monteiro, R.T.R. (2007) Indicadores biológicos de qualidade do solo. Bioscience J 23(3).

2. Breslauer, K.J., Frankm R., Blocker, H., Marky, L.A. (1986) Predicting DNA figduplex stability from the base sequence. Proc Natl Acad Sci USA 83, 3746-3750.

3. Coyne, K.J., Hutchins, D.A., Hare, C.E., Cary, S.C. (2001) Assessing temporal and spatial variability in Pfiesteria piscicida distributions using molecular probing techniques. Aquat Microb Ecol 24, 275-285.

4. Derakshani, M., Lukow, T., Liesack, W. (2001) Novel bacterial lineages at the (sub) division level as detected by signature nucleotide-targeted recovery of $16 \mathrm{~S}$ rRNA genes from bulk soil and rice roots of flooded rice microcosms. Appl Environ Microbiol 67, 623-631.

5. Diaz, H., Miska, S., Takach, N., Yu, M. (2004) Modeling of ECD in casing drilling operations and comparison with experimental and field data. In: IADC/SPE Drilling Conference. Society of Petroleum Engineers.

6. Elsas, J.D.V., Smalla, K. (1995) Extraction of microbial community DNA from soils. In: Molecular Microbial Ecology Manual (pp. 61-71). Springer Netherlands.

7. EMBRAPA - Empresa Brasileira de Pesquisa Agropecuária. (2013) Sistema Brasileiro de Classificação de Solos. $3^{\mathrm{a}}$ Edição 353p.

8. Fam, M.A., Dusseault, M.B. (1998) Borehole stability in shales: a physico-chemical perspective. In: SPE/ISRM Rock
Mechanics in Petroleum Engineering. Society of Petroleum Engineers.

9. Ferreira, E.P.B., Nunes, M.U.C., Xavier, G.R., Rumjanek, N.G. (2009) Perfis de PCR-DGGE de comunidades bacterianas associadas ao rizoplano de milho sob diferentes doses de adubação com compostos orgânicos. Bioscience J 25(3).

10. Freitas, F.C. (2009) Dissertation. Uso de resíduo orgânico da produção de biodiesel direta da semente na atenuação dos efeitos de hidrocarbonetos de petróleo no solo. UFRRJ/IA

11. Freitas, F.C.D., Presotto, R.A., Genúncio, G.D.C., Sobrinho, N.M.B.D.A., Zonta, E. (2015) pH, sodium, potassium, calcium, magnesium and aluminum in soils contaminated with petroleum drilling fluid after leaching tests. Ciência Rural 45, 1418-1423.

12. Kane, D.J., Sarafian, T.A., Anton, R., Hahn, H., Gralla, E.B., Valentine, J.S., Bredesen, D.E. (1993) Bcl-2 inhibition of neural death: decreased generation of reactive oxygen species. Science 262, 1274-1277.

13. Kirk, J.L., Beaudette, L.A., Hart, M., Moutoglis, P., Klironomos, J.N., Lee, H., Trevors, J.T. (2004) Methods of studying soil microbial diversity. J Microbiol Methods 58, 169-188.

14. Magalhães, M.O.L., do Amaral Sobrinho, N.M.B., Zonta, E., de Carvalho, M.M., Tolón-Becerra, A. (2012) Effect of variations in the redox potential of Gleysol on barium mobility and absorption in rice plants. Chemosphere 89, 121127.

15. Marciano, C.R., Moraes, S.O., Oliveira, F.C., Mattiazzo, M.E. (2001) Efeito do lodo de esgoto e do composto de lixo urbano sobre a condutividade hidráulica de um Latossolo Amarelo saturado e não saturado. R Bras Ci Solo 25, 1-9.

16. Muyzer, G., De Waal, E.C., Uitterlinden, A.G. (1993) Profiling of complex microbial populations by denaturing gradient gel electrophoresis analysis of polymerase chain reaction-amplified genes coding for $16 \mathrm{~S}$ rRNA. Appl Environ Microbiol 59, 695-700.

17. Oliveira, S.D. (2008) Dissertation. Avaliação das técnicas de bioaumento fúngico e bioestímulo em processos de biorremediação utilizando solo contaminado por petróleo. $\mathrm{UFRJ} / \mathrm{EQ}$.

18. Ovreås, L., Forney, L., Daae, F.L., Torsvik, V. (1997) Distribution of bacterioplankton in meromictic Lake Saelenvannet, as determined by denaturing gradient gel electrophoresis of PCR-amplified gene fragments coding for 16S rRNA. Appl Environ Microbiol 63, 3367-3373.

19. Pires, A.M.M., Mattlazzo, M.E. (2008) Avaliação da Viabilidade do Uso de Resíduos na Agricultura. Circular Técnica, EMBRAPA, Jaguariúna, SP, 2008.

20. Presotto, R.A. (2014) Dissertation. Efeito da Salinidade do Cascalho de Perfuração de Poços de Petróleo no Cultivo de Girassol. UFRRJ/IA.

21. SAS Institute Inc. (2010) SAS OnlineDoc® 9.2.SAS Institute Inc

22. Silva, R.B.D. (2013) Dissertation. Substituição de farelo de soja por torta de crambe para ovinos em crescimento. UFLA.

23. Suzuki, M.T., Giovannoni, S.J. (1996) Bias caused by template annealing in the amplification of mixtures of $16 \mathrm{~S}$ rRNA genes by PCR. Appl Environ Microbiol 62, 625-630.

24. Torsvik, V., Øvreås, L. (2002) Microbial diversity and function in soil: from genes to ecosystems. Curr Opin Microbiol 5, 240-245.

25. Zilli, J.É., Rumjanek, N.G., Xavier, G.R., Costa, C.H.L., Neves, M.C.P. (2003) Diversidade microbiana como indicador de qualidade do solo. Cadernos de Ciência \& Tecnologia,

391-411. 
Table 1. Chemical characteristics and number of OTUs (Operational Taxonomic Units) in soils treated with different combinations of Crambe press cake and gravel after 60 days

\begin{tabular}{|c|c|c|c|c|c|c|c|}
\hline Gravel & $\begin{array}{l}\text { Crambe } \\
\text { presscake }\end{array}$ & $\mathrm{pH}_{\dagger}^{\dagger}$ & $\mathrm{Na}+$ & $\mathrm{K}+$ & $\mathrm{Ca} 2+$ & $\mathrm{Mg} 2+$ & $\begin{array}{l}\text { Average } \\
\text { numbers } \\
\text { OTUst }\end{array}$ \\
\hline 0 & 0 & 4,85 & 0,09 & 0,41 & 3,97 & 3,70 & 21,50 \\
\hline 0 & 16 & 5,91 & 0,19 & 3,25 & 5,90 & 5,33 & 24,00 \\
\hline 0 & 32 & 5,06 & 0,39 & 6,38 & 8,63 & 7,87 & 22,50 \\
\hline 30 & 0 & 5,73 & 28,93 & 0,61 & 16,73 & 7,43 & 20,50 \\
\hline 30 & 16 & 5,96 & 29,24 & 3,02 & 19,57 & 6,93 & 25,00 \\
\hline 30 & 32 & 5,99 & 40,23 & 7,10 & 23,90 & 12,43 & 27,50 \\
\hline 60 & 0 & 6,11 & 51,89 & 1,39 & 27,57 & 9,47 & 24,00 \\
\hline 60 & 16 & 6,19 & 68,21 & 3,74 & 29,93 & 10,27 & 20,00 \\
\hline 60 & 32 & 6,24 & 56,55 & 6,06 & 34,80 & 13,77 & 21,50 \\
\hline
\end{tabular}

$\dagger \mathrm{pH}$ in water. $\$$ Average number of bands (operational taxonomic units) in the two DGGE gels

Table 2. Sequence analysis of bands excised from DGGE gel from samples of haplic planosol treated with combinations of energy industry wastes

\begin{tabular}{llll}
\hline \multicolumn{1}{l}{ Identification of excised } & & \\
band & Closest relative & Identity & Accession no. \\
\hline S1 & Uncultured bacterium isolate & EF366387.1 \\
S2 & Uncultured bacterium clone & $94 \%$ & JF194885.1 \\
S3 & Virgibacillus sp. & KJ584890.1 \\
S4 & Uncultured bacterium clone & $87 \%$ & KF096722.1 \\
S5 & Uncultured microorganism clone & $92 \%$ & JN915056.1 \\
S6 & Uncultured bacterium clone & KF110654.1 \\
S7 & Uncultured bacterium clone & JF163311.1 \\
S8 & Uncultured bacterium clone & $88 \%$ & JF162119.1 \\
S9 & Uncultured bacterium clone & JF162243.1 \\
S10 & Uncultured bacterium clone & $85 \%$ & JF114851.1 \\
S11 & Uncultured microorganism clone & JN915084.1 \\
S12 & Uncultured bacterium clone & $97 \%$ & JF143760.1 \\
S13 & Uncultured bacterium clone & $91 \%$ & JF427841.1 \\
S14 & Uncultured bacterium clone & $91 \%$ & JF122902.1 \\
S15 & Uncultured bacterium clone & $97 \%$ & JF109824.1 \\
S16 & Uncultured bacterium clone & $94 \%$ & JF192610.1 \\
S17 & Uncultured bacterium clone & $98 \%$ & KF092445.1 \\
S18 & Uncultured bacterium clone & JF165298.1 \\
S19 & Bacillus sp. & JX274439.3 \\
\hline
\end{tabular}

Table 3. Chemical characterization of Crambe presscake and gravel

\begin{tabular}{|c|c|c|c|c|c|c|c|c|c|c|c|c|}
\hline \multirow{2}{*}{\multicolumn{2}{|c|}{$\mathrm{pH} \dagger+$}} & $\mathrm{N}$ & $\mathrm{P}$ & $\mathrm{K}+$ & $\begin{array}{r}\mathrm{Ca} 2+ \\
\mathrm{g}\end{array}$ & $\begin{array}{l}\mathrm{Mg} 2+ \\
\mathrm{kg}-\end{array}$ & $\mathrm{Na}+$ & $\mathrm{Fe}$ & $\mathrm{Cu}$ & $\mathrm{Mn}$ & $\begin{array}{c}\mathrm{Zn} \\
\mathrm{mg} \mathrm{kg}\end{array}$ & PHCst \\
\hline & & 1. & & & & & & 1 & & & & \\
\hline Crambe presscake & 5,12 & 38,9 & 3,12 & 8,7 & 8,6 & 3,1 & 0,0 & 140 & 5,4 & 22,1 & 44,5 & - \\
\hline Gravel & 6,83 & 1,77 & 0,56 & 3,3 & 31,8 & 15,2 & 38,5 & 30.053 & 40,4 & 646 & 67,2 & 20,27 \\
\hline
\end{tabular}


$\dagger \mathrm{pH}$ in water. $₫$ Petroleum hydrocarbons

\section{Figures}
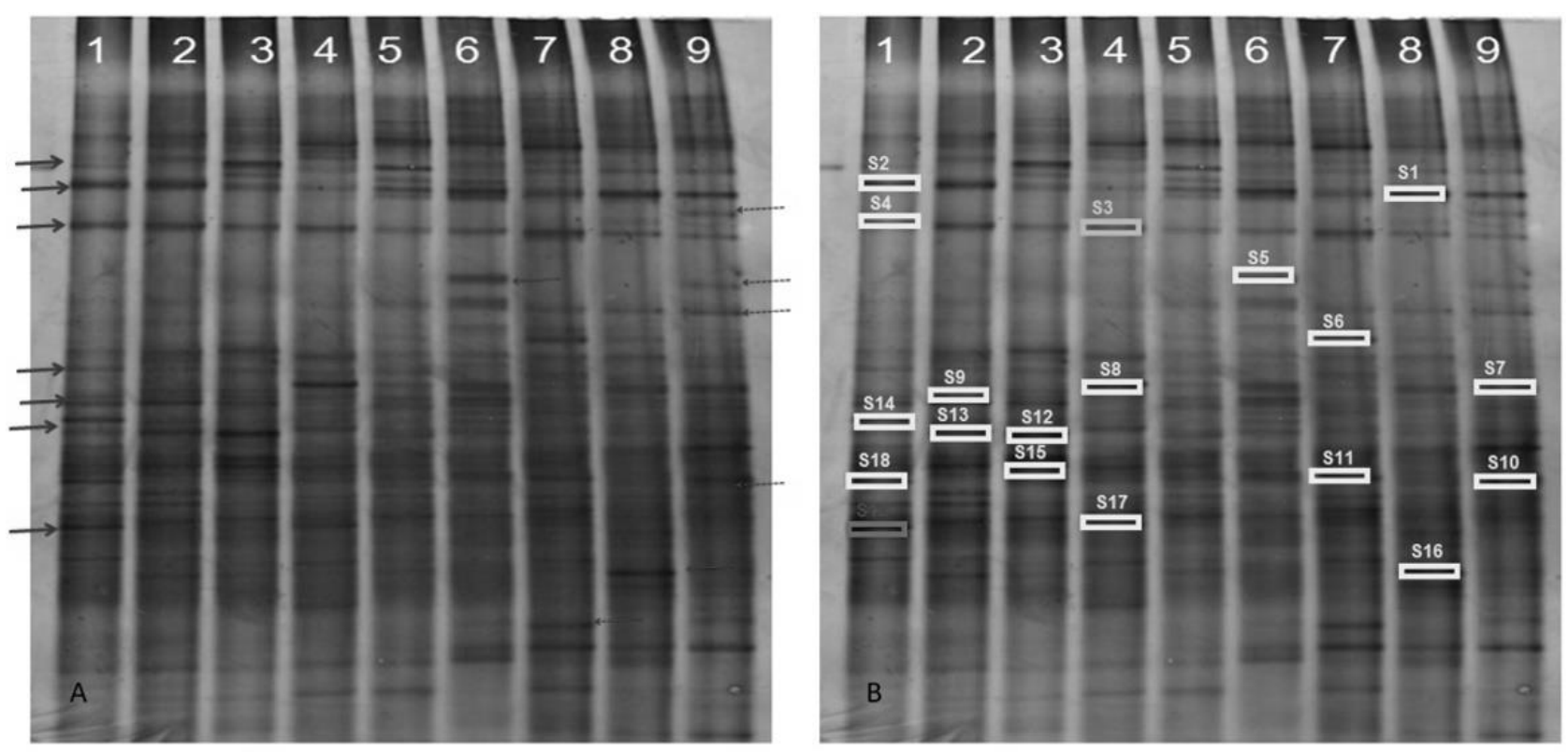

| Isolado Bacteriano não cultivado

Bacillus spp.

Virgibacillus $\mathrm{sp}$,

Fig. 1. A: Denaturing gradient gel electrophoresis of amplicons produced using nested PCR with CG338F/518R primers: $1=0 / 0 ; 2=16 / 0 ; 3=32 / 0 ; 4=0 / 30 ; 5=16 / 30 ; 6=32 / 30 ; 7=0 / 60 ; 8=16 / 60 ;$ and $9=32 / 60$. B: Identification of the sequenced bands.

Repetição 1

Repetição 2

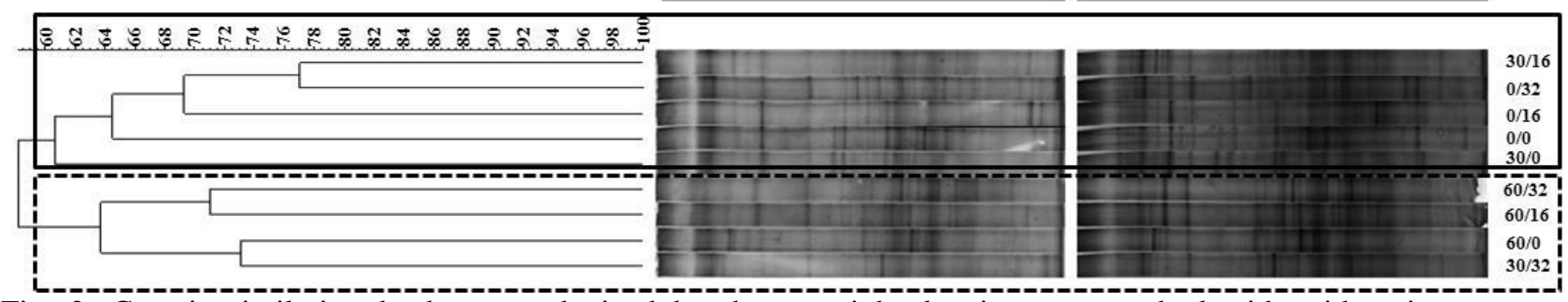

Fig. 2. Genetic similarity dendrogram obtained by the unweighted pair group method with arithmetic mean clustering method, and the pattern of amplicons corresponding to the $16 \mathrm{~S}$ rDNA gene obtained using PCR-DGGE from soil samples treated with different combinations of gravel and Crambe press cake. Soil samples treated with 0/0,0/16, 0/32, 30/0,30/16, 30/32, 60/0,60/16, and 60/32 Mg ha-1 of gravel/Crambe press cake. 